\title{
Synthesis of furanoid and pyranoid C-1 aryl glycals by reaction of glycosyl chlorides with organolithium reagents
}

\author{
Ana M. Gómez,* Marta Casillas, Benjamín Rodríguez, \\ Serafín Valverde, and J. Cristóbal López* \\ Instituto de Química Orgánica General, CSIC, \\ Juan de la Cierva 3, 28006, Madrid, Spain \\ E-mail address: anagomez@iqog.csic.es,clopez@iqog.csic.es
}

Dedicated to Prof. Benito Alcaide on the occasion of his $60^{\text {th }}$ birthday

\begin{abstract}
Furanosyl and pyranosyl chlorides react with aryllithium derivatives, obtained by directed ortholithiation of activated arenes, to give C-1 aryl glycals in moderate yields.
\end{abstract}

Keywords: Glycals, C-glycosides, organolithium reagents, glycosyl chlorides

\section{Introduction}

The term glycal is used to define aldose derivatives having a double bond between $\mathrm{C}-1$ and $\mathrm{C}-2$, e.g. 1. ${ }^{1}$ Accordingly, C-1 glycals are $\Delta^{1,2}$ unsaturated carbohydrate derivatives with a carbon substituent at the anomeric position, e.g. 2. These compounds are versatile synthetic intermediates, owing to the variety of transformations associated with their enol ether functionality, and have found ample use in the preparation of $C$-glycosides, e.g. $3,{ }^{2}$ carbohydrate mimics, ${ }^{3}$ and natural products ${ }^{4}$.

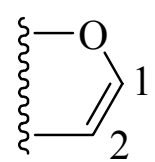

Glycal

1

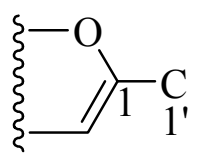

C-1 glycal

2

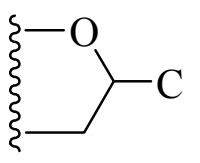

C-glycoside

3

Figure 1 
The preparation of C-1 glycals has been largely addressed by synthetic modifications on cyclic carbohydrate derivatives, ${ }^{5}$ although strategies that rely on ring forming reactions from acyclic derivatives have recently emerged. ${ }^{6,7}$ Most of the synthetic routes to C-1 glycals from cyclic carbohydrate derivatives are based on the deprotonation of glycals, which was independently reported by three research groups. ${ }^{8,9,10}$ The ensuing lithiated species are then able to react with various carbon electrophiles, or with tributyltin chloride. The former approach leads directly to $\mathrm{C}-1$ glycals, and the latter have been harnessed to palladium-mediated cross-coupling reactions for the key $\mathrm{C} 1-\mathrm{C} 1$ ' bond forming step. ${ }^{11,12,13}$ On the other hand, lactones have also been used as starting materials in the synthesis of C-1 glycals, ${ }^{14}$ in this case unlike the previous one the carbohydrate functions as an electrophile.

As part of our interest in the preparation of C-1 glycals, ${ }^{15}$ we reported, some time ago, a route to both $C$-aryl and $C$-alkyl pyranoid glycals based on the of reaction of anomeric glycosyl chlorides, e.g. 6, with commercially available organolithium reagents, where the carbohydrates exerted as the electrophilic partner. ${ }^{16,17}$ We have since evaluated the scope of the approach ${ }^{18}$ and, in this paper, we describe the preparation of furanoid and pyranoid C-1 aryl glycals from the reaction of furanosyl and pyranosyl chlorides with aryllithium derivatives generated by directed ortho-metalation of aromatic derivatives, vide infra. Furthermore, the furanoid C-1 glycals prepared in this study can be easily transformed into homochiral 2,5-disubstituted furans.

\section{Results and Discussion}

For our study we selected compound $\mathbf{6}$, as the furanosyl chloride representative. Chloride $\mathbf{6}$ was easily prepared in two steps from D-mannose (4) by thermodynamically controlled acetonation ${ }^{19}$ followed by anomeric chlorination ${ }^{20}$ (Scheme 1).

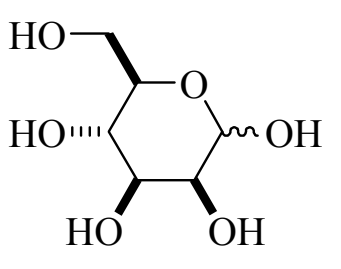

4

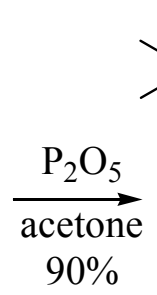

$90 \%$

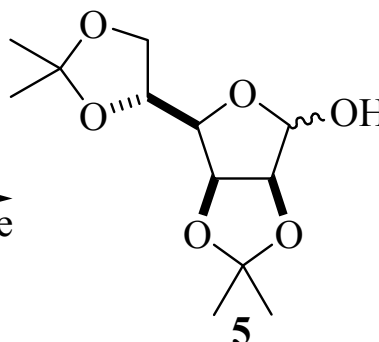

5

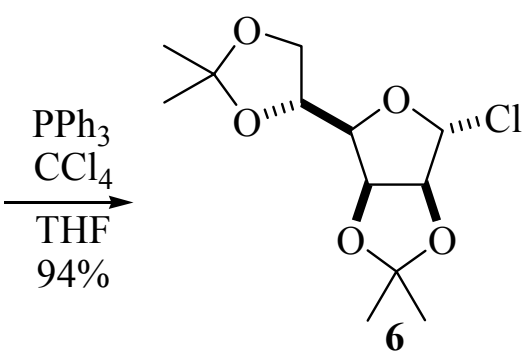

Scheme 1. Synthesis of furanosyl chloride 6.

As pyranosyl chloride, we selected 6-deoxy derivative 15, since a related compound had been used by Tius and co-workers in their synthetic approach to vineomicinone B2 methyl ester. $^{21}$ In our synthetic scheme to chloride 15, we visualized thioglycoside $\mathbf{1 2}$ as the key intermediate (Scheme 2a). Our synthetic scheme started with tosyl derivative 8, conveniently 
prepared from thioglycoside 7, by treatment with tosyl chloride (pyridine, $0{ }^{\circ} \mathrm{C}$ ) in $65 \%$ yield (Scheme 2a). From compound 8, we evaluated three different routes to 12: $i$ ) the direct treatment of tosylate $\mathbf{8}$ with lithium aluminum hydride produced triol $\mathbf{9}$, albeit in only $30 \%$ yield, from which the isopropylidene ring was installed in $60 \%$ yield; ii) a second route involving nucleophilic substitution of tosylate $\mathbf{8}$ with $\mathrm{NaI}$ followed by radical dehalogenation $\left(\mathrm{HSnBu}_{3}\right.$, AIBN) of the ensuing iodide, gave triol 9, in $85 \%$ yield; iii) the best route proved to be acetonation of the tosylate ( $85 \%$ yield) followed by $\mathrm{H}_{4} \mathrm{LiAl}$ reduction ( $87 \%$ yield). Once we had compound 12, in hand, we proceeded with its benzylation, oxidative hydrolysis, and chlorination to gain access to glycosyl chloride $\mathbf{1 5}$.

Before attempting the reaction of glycosyl chlorides $\mathbf{6}$ and $\mathbf{1 5}$ with complex aryllithium reagents, we decided to test their reaction with, commercially available, $\mathrm{PhLi}$. In agreement with our previous results, ${ }^{16,18}$ we found they both led to the expected C-1 phenyl glycals in moderate yields (Scheme 3).

(a)

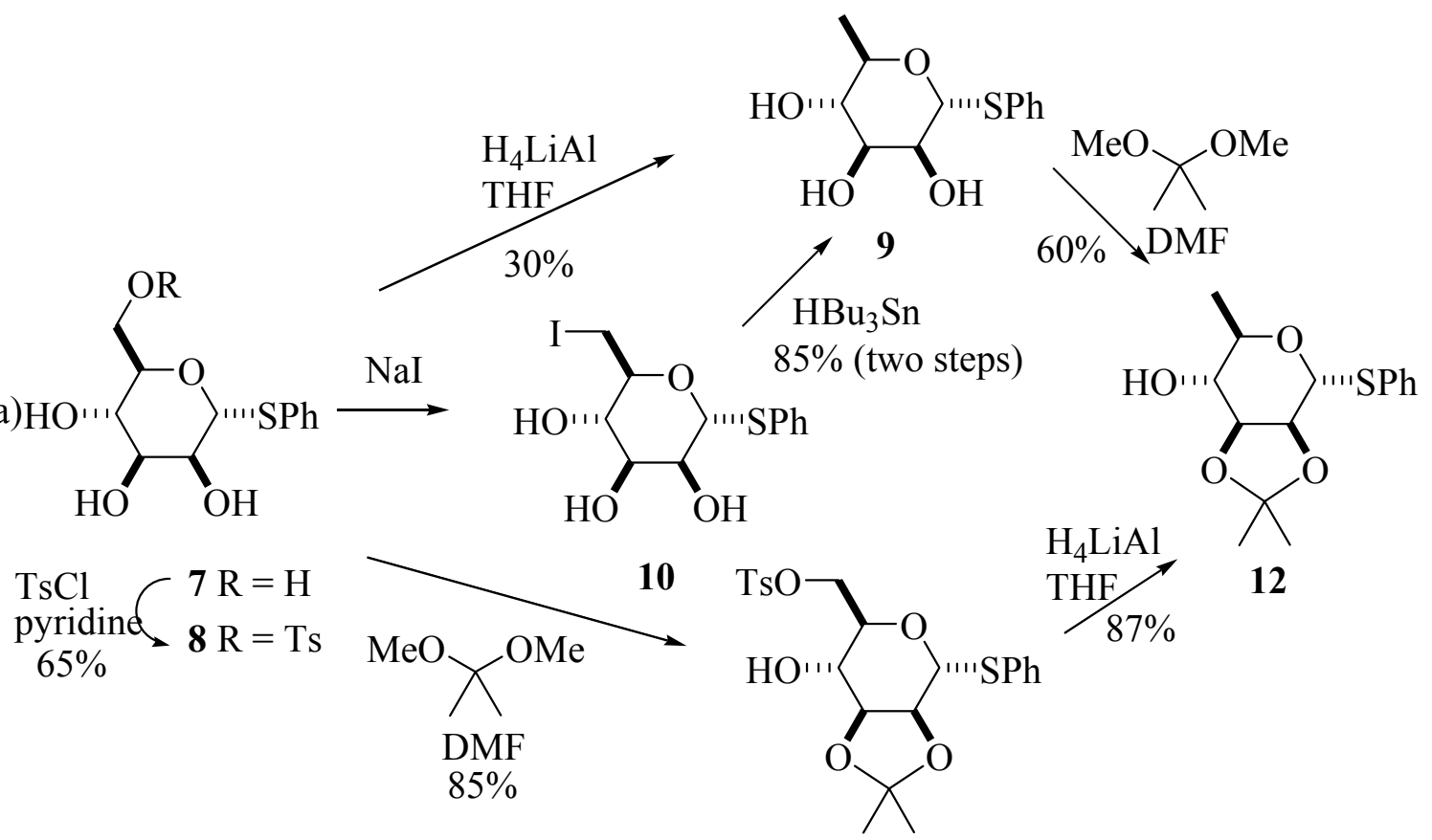

(b) $12 \underset{\substack{\mathrm{NaH} \\ 90 \%}}{\stackrel{\mathrm{BnBr}}{\longrightarrow}}$

Scheme 2. Synthesis of pyranosyl chloride 15 from thiomannoside 7. 

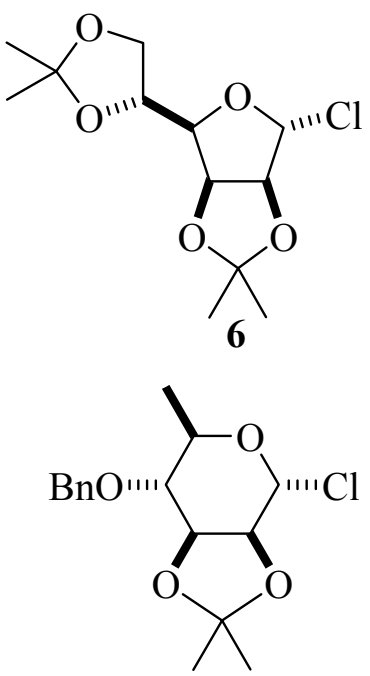

15

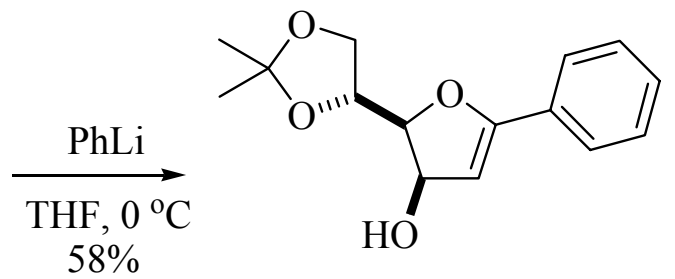

16

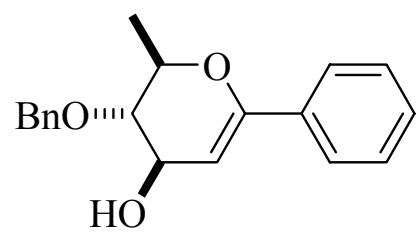

17

Scheme 3. Reaction of glycosyl chlorides 6 and 15 with PhLi.

We next turned our attention to the use of aryl organilithium reagents other than commercially available, $\mathrm{PhLi}$. We envisaged that aryllithium derivatives generated by directed ortho-metalation, ${ }^{22}$ could be used in the preparation of C-1 glycals. Accordingly, 2-lithio 1methoxy naphthalene generated by reaction of 1-methoxy naphthalene with $t$-BuLi, reacted with furanosyl chloride 6, to furnish C-1 glycal 18, in 46\% yield (Scheme 4a). We also carried out the directed ortho-metalation on 2-methoxy naphthalene, and 1-naphthol, and the results are shown in Scheme 4b,c, respectively. Varying amounts of furans 19 and 21 were observed in the crude reaction mixture of chloride 6 with the lithium salts of 1- and 2-methoxynaphthalene (Scheme $4 a, b)$. These aryl glycals proved to be highly sensitive to acid and temperature, and so the low yield of compound 22 (Scheme 4c, obtained along with $\mathbf{2 3}$ as an inseparable mixture) could be rationalized because of the presence of the acidic phenolic $\mathrm{OH}$ group. According to that, we were able to prepare homochiral furans 19 and 21, in quantitative yield from the corresponding C-1 glycals 18 and 19, upon treatment with silicagel in dichloromethane. The presence of $\mathrm{NEt}_{3}$ in the reaction work-up, and in the eluent for column chromatography, has a beneficial effect in preventing this transformation. 


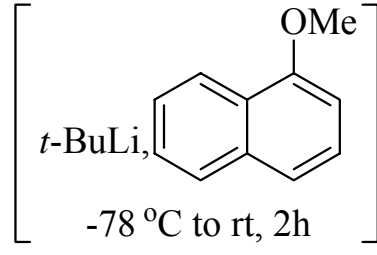

(a) 6

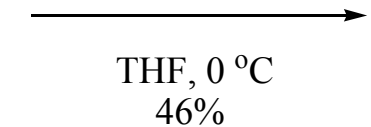<smiles>C/C=C/C(C)C1=C[C@@H](O)[C@H]([C@H]2COC3(C)CC3C2)O1</smiles>

18<smiles>COc1c(C)ccc2cccc(-c3ccc([C@H]4COC(C)(C)O4)o3)c12</smiles>

19 (b) 6<smiles>Cc1ccc2ccccc2c1</smiles>

THF, $0{ }^{\circ} \mathrm{C}$ $35 \%$<smiles>COc1cc2ccccc2cc1C1=C[C@@H](O)[C@H](C2COC(C)(C)O2)O1</smiles>

20
$\mathrm{CH}_{2} \mathrm{Cl}_{2}$

$100 \%$

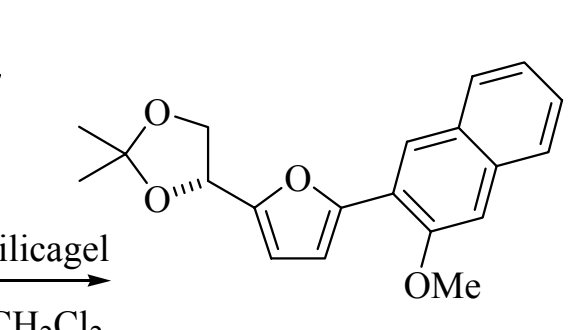

21

(c) 6

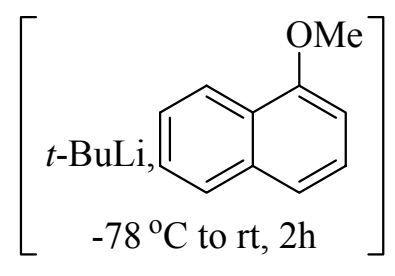

THF, $0{ }^{\circ} \mathrm{C}$ to rt, $3 \mathrm{~h}$<smiles>CC1(C)OC[C@H]([C@H]2OC(c3ccc4ccccc4c3O)=C[C@H]2O)O1</smiles>

22

$15 \%$<smiles>CC1(C)OC[C@H](c2ccc(-c3ccc4ccccc4c3O)o2)O1</smiles>

23

$9 \%$

Scheme 4. Reaction of furanosyl chloride 6 with aryl lithiums generated by directed orthometalation, and furan formation.

Finally, we decided to test the reaction of lithiated of 1,5-bis(methoxyethoxy)-anthracene (26), with pyranosyl chloride 15, since the expected C-1 glycal will be related to a synthetic intermediate employed by Tius and co-workers in their approach to vineomycinone B2 methyl ester. $^{21}$ We prepared compound $\mathbf{2 6}$ from commercially available anthrarufin (1,5-dihydroxy9,10-anthraquinone) $\mathbf{2 4}$, by methoxyethoxylation followed by sodium borohydride reduction (Scheme 5a). Subsequent, lithiation ( $n$-BuLi, THF, $-78{ }^{\circ} \mathrm{C}$ to $-10{ }^{\circ} \mathrm{C}$ ) of $\mathbf{2 6}$ and reaction with chloride 15, yielded C-1 glycal 27, in 9\% yield, along with hemiacetal 28 (78\%). 
(a)

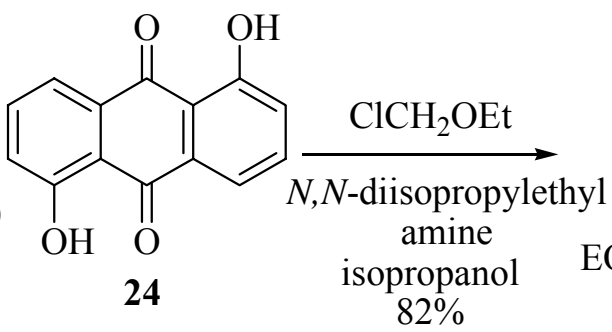

(b)

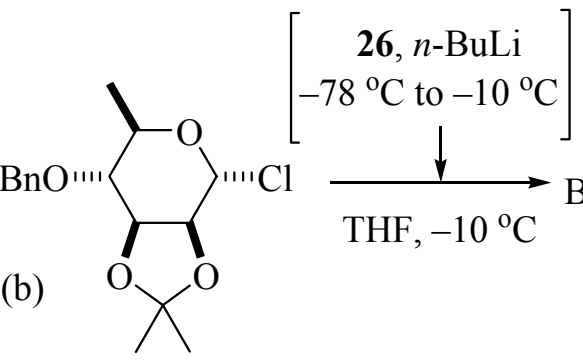
15<smiles>COc1cccc2c1C(=O)c1cccc(OC)c1C2=O</smiles>

25<smiles>CCOc1cccc2cc3c(OCC)cccc3cc12</smiles>

26

Scheme 5. Synthesis of C-1 glycal 27, from pyranosyl chloride 15.

\section{Conclusions}

C-1 Aryl glycosides can be prepared in moderate yields by the reaction of glycosyl chlorides with functionalized aryllithium derivates. The latter can be accesed by directed ortho-metalation of the corresponding activated arenes. C-1 Aryl glycals ensuing from furanosyl chloride 6, have proven to be sensitive to acid and temperature, thus evolving to the corresponding furan derivatives.

\section{Experimental Section}

General Procedures. All reactions were performed in dry flasks fitted with glass stoppers or rubber septa under a positive pressure of Ar, unless otherwise noted. Air- and moisture-sensitive liquids and solutions were transferred by syringe or stainless steel cannula. Optical rotations were determined for solutions in chloroform. Flash column chromatography was performed using 230-400 mesh silica gel. Thin-layer chromatography was conducted on Kieselgel 60 F254 (Merck). Spots were observed first under UV irradiation $(254 \mathrm{~nm})$ then by charring with a solution of $20 \%$ aqueous $\mathrm{H} 2 \mathrm{SO} 4(200 \mathrm{~mL})$ in $\mathrm{AcOH}(800 \mathrm{~mL})$. Anhydrous $\mathrm{MgSO}_{4}$ or $\mathrm{Na}_{2} \mathrm{SO}_{4}$ were used to dry organic solutions during workup, and evaporation of the solvents was 
performed under vacuum using a rotary evaporator. Solvents were dried and purified using standard methods. Unless otherwise noted ${ }^{1} \mathrm{H}$ and ${ }^{13} \mathrm{C}$ NMR spectra were recorded in $\mathrm{CDCl}_{3}$ at $300 \mathrm{MHz}$ and $50 \mathrm{MHz}$, respectively. Chemical shifts are expressed in parts per million ( $\delta$ scale) downfield from tetramethylsilane and are referenced to residual protium in the NMR solvent $\left(\mathrm{CHCl}_{3}: \delta 7.25 \mathrm{ppm}\right)$. Elemental analyses were carried out at the Centro Nacional de Quimica Orgánica "Manuel Lora Tamayo", Juan de la Cierva 3, 28006 Madrid, with a Heraeus CHN-Orapid elemental analyzer.

2,3:5,6-Di-O-isopropylidene- $\alpha$-D-mannofuranosyl chloride (6). 2,3:5,6-di-O-isopropylideneD-mannofuranose $5^{19}(5 \mathrm{~g}, 19.2 \mathrm{mmol})$ and $\mathrm{PPh}_{3}(10.1 \mathrm{~g}, 38.6 \mathrm{mmol})$ were dissolved in dry THF $(50 \mathrm{~mL})$ and then $\mathrm{CCl}_{4}(9.4 \mathrm{~mL}, 97.5 \mathrm{mmol})$ was added. The mixture was heated to reflux with exclusion of moisture. After the reaction was complete, $\mathrm{Ph}_{3} \mathrm{PO}$ was filtered, the solid was washed with THF, and the filtrate was evaporated in vacuo. The resultant material was purified by flash chromatography (EtOAc/hexane $5 \%$ ) to yield glycosyl chloride $6^{23}(5.1 \mathrm{~g}, 95 \%)$ : $[\alpha]_{\mathrm{D}}{ }^{25}$ +52.0 (c 1.30 in $\left.\mathrm{CHCl}_{3}\right) ;{ }^{1} \mathrm{H}$ NMR $\delta\left(\mathrm{CDCl}_{3}, 300 \mathrm{MHz}\right) 1.33(3 \mathrm{H}, \mathrm{s}, \mathrm{Me}), 1.38(3 \mathrm{H}, \mathrm{s}, \mathrm{Me}), 1.46$ (3 H, s, Me), 1.47 (3 H, s, Me), $3.99(1 \mathrm{H}, \mathrm{dd}, J=4.4,8.8 \mathrm{~Hz}, 6-\mathrm{H}), 4.08(1 \mathrm{H}, \mathrm{dd}, J=5.9,8.8$ $\mathrm{Hz}, 6-\mathrm{H}), 4.20(1 \mathrm{H}, \mathrm{dd}, J 3.4,7.8 \mathrm{~Hz}, 4-\mathrm{H}), 4.42(1 \mathrm{H}$, ddd, $J=4.4,5.9,7.8 \mathrm{~Hz}, 5-\mathrm{H}), 4.88(1 \mathrm{H}$, dd, $J$ 3.4, 5.6, 3-H), $4.96(1 \mathrm{H}, \mathrm{d}, J=5.6,2-\mathrm{H}) ; 6.06(1 \mathrm{H}, \mathrm{s}, 1-\mathrm{H}) ;{ }^{13} \mathrm{C} \mathrm{NMR} \delta\left(\mathrm{CDCl}_{3}, 50 \mathrm{MHz}\right)$ 24.7, 25.2, 25.6, 27.0, 66.8, 72.4, 78.6, 82.4, 89.3, 97.7, 109.6, 113.4; API-ES(+) $279.1\left(\mathrm{M}^{+}+1\right.$. $\mathrm{C}_{12} \mathrm{H}_{19} \mathrm{ClO}_{5}$ requires 278.0921).

Phenyl 6-O-(p-toluenesulfonyl)-1-thio- $\alpha$-D-mannopyranoside (8). Phenyl 1-thio- $\alpha$-Dmannopyranoside 6 (6 g, $22.06 \mathrm{mmol})$ was treated with $p$-toluene-sulfonyl chloride $(5.4 \mathrm{~g}$, $28.7 \mathrm{mmol})$ in dry pyridine $(100 \mathrm{~mL})$ at $0{ }^{\circ} \mathrm{C}$. The reaction was allowed to warm to room temperature and after 5 hours of stirring, the mixture was concentrated in vacuo, diluted with $\mathrm{CH}_{2} \mathrm{Cl}_{2}$, washed with aqueous $\mathrm{NaHCO}_{3}$ and water. The organic layer was then dried over $\mathrm{MgSO}_{4}$, filtered and concentrated. Flash chromatography $\left(\mathrm{CH}_{2} \mathrm{Cl}_{2} / \mathrm{MeOH} 92: 8\right)$ of the residue afforded $\mathbf{8}^{24}(7.04 \mathrm{~g}, 75 \%)::[\alpha]_{\mathrm{D}}{ }^{21}+148\left(c 0.4\right.$ in $\left.\mathrm{CHCl}_{3}\right) ;{ }^{1} \mathrm{H}$ NMR $\left(200 \mathrm{MHz}, \mathrm{CDCl}_{3}\right) \delta 7.67-$ 7.73 (m, $2 \mathrm{H}), 7.20-7.40$ (m, $7 \mathrm{H}), 5.46$ (s, 1H, H1), 4.12-4.40 (m, $4 \mathrm{H}), 3.75-3.90$ (m, $2 \mathrm{H})$, $2.35(\mathrm{~s}, 3 \mathrm{H}) ;{ }^{13} \mathrm{C}$ NMR $\left(50 \mathrm{MHz}, \mathrm{CDCl}_{3}\right) \delta 144.5,133.5,132.4,131.3,129.5,128.6,127.7$, 127.1, 87.8, 71.9, 71.8, 70.9, 69.1, 67.1, 60.1. Anal. Calcd for $\mathrm{C}_{19} \mathrm{H}_{22} \mathrm{O}_{7} \mathrm{~S}_{2}$ (426.0807): C, 53.50; H, 5.20. Found: C, 53.71; H, 5.27.

Phenyl 1-thio- $\alpha$-D-rhamnopyranoside (9). Method A. A solution of compound 8 (1.87 g, $4.38 \mathrm{mmol})$ in dry THF $(10 \mathrm{~mL})$ was added to a cooled $\left(0{ }^{\circ} \mathrm{C}\right)$ suspension of $\mathrm{LiAlH}_{4}(5.6 \mathrm{~g}$, $17.52 \mathrm{mmol})$ in dry THF $(20 \mathrm{~mL})$. The mixture was allowed to warm to room temperature and then stirred for an additional $24 \mathrm{~h}$ period. The reaction mixture was recooled to $0{ }^{\circ} \mathrm{C}$, diluted with $\mathrm{Et}_{2} \mathrm{O}(100 \mathrm{~mL})$ and then carefully treated with saturated $\mathrm{Na}_{2} \mathrm{SO}_{4}$ solution $(1 \mathrm{~mL})$. The mixture was stirred for $20 \mathrm{~min}$, after which time was filtered though a short pad of celite and concentrated. The residue was purified by flash chromatography. $\left(\mathrm{CH}_{2} \mathrm{Cl}_{2} / \mathrm{MeOH}\right.$ 95:5) to afford pure 9 (336 mg, $30 \%) .{ }^{1} \mathrm{H}$ NMR. $\left(200 \mathrm{MHz}, \mathrm{CDCl}_{3}\right) \delta .7 .22-7.45$ (m, 5H), $5.46(\mathrm{~s}, 1 \mathrm{H}, \mathrm{H1})$, 
3.50-4.20 (m, 7H), $1.30(\mathrm{~d}, \mathrm{~J}=6.1 \mathrm{~Hz}, 3 \mathrm{H}) ;{ }^{13} \mathrm{C} \mathrm{NMR}\left(50 \mathrm{MHz}, \mathrm{CDCl}_{3}\right) \oint 134.2,131.2,128.9$, 127.2, 87.9, 73.0, 72.5, 72.1, 69.4, 29.5. $\mathrm{m} / \mathrm{z} 256.0\left(\mathrm{M}^{+}\right)$.

Method B. A mixture of compound 8 (1.87 g, $4.38 \mathrm{mmol})$, and NaI (860 mg, $5.72 \mathrm{mmol})$ in 2butanone $(50 \mathrm{~mL})$ was boiled under reflux for $16 \mathrm{~h}$. After cooling, the reaction mixture was filtered and concentrated. The residue was immediately dissolved in $t-\mathrm{BuOH}(25 \mathrm{~mL})$, heated to $90{ }^{\circ} \mathrm{C}$ treated with $\mathrm{HSnBu}_{3}(1.5 \mathrm{~mL}, 5.7 \mathrm{mmol})$ and AIBN $(150 \mathrm{mg}, 0.91 \mathrm{mmol})$ and stirred at that temperature for $20 \mathrm{~h}$. After cooling to room temperature, the mixture was diluted with EtOAc $(200 \mathrm{~mL})$, washed with water, dried $\left(\mathrm{MgSO}_{4}\right)$ and concentrated. Column chromatography $\left(\mathrm{CH}_{2} \mathrm{Cl}_{2} / \mathrm{MeOH}\right.$ 95:5) of the residue gave 9 (960 mg, 85\%).

Phenyl 2,3-O-isopropylidene-6-O-(p-toluenesulfonyl)-1-thio- $\alpha$-D-mannopyranoside (11). $p$ Toluenesulfonic acid monohydrate (100 mg) and 2,2-dimethoxypropane (2.6 mL, $11 \mathrm{mmol})$ were added to a solution of $8(4.5 \mathrm{~g}, 10.5 \mathrm{mmol})$ in dry DMF $(50 \mathrm{~mL})$. After $7 \mathrm{~h}, \mathrm{NaHCO}_{3}$ was added and the mixture was diluted with $\mathrm{CH}_{2} \mathrm{Cl}_{2}$, washed with water, dried $\left(\mathrm{Na}_{2} \mathrm{SO}_{4}\right)$, filtered and concentrated. Purification by flash chromatography (Hexane/EtOAc 7:3) yielded 11 (4.2 g, 85\%): $[\alpha]_{\mathrm{D}}{ }^{21}+102.2$ (c 1.1 in $\mathrm{CHCl}_{3}$ ); ${ }^{1} \mathrm{H}$ NMR (200 MHz, $\left.\mathrm{CDCl}_{3}\right) \delta 7.71-7.24(\mathrm{~m}, 9 \mathrm{H}), 5.68$ (s, $1 \mathrm{H}, \mathrm{H1}$ ), 4.32-4.11 (m, 5 H), 3.75-3.64 (m, 1 H, H4), 2.75 (d, J = 4.4 Hz, 1 H, OH), 2.40 (s, 3H), 1.49 (s, $3 \mathrm{H}), 1.34$ (s, $3 \mathrm{H}) ;{ }^{13} \mathrm{C}$ NMR $\left(50 \mathrm{MHz}, \mathrm{CDCl}_{3}\right) \oint 144.6,132.4,132.3,132.0,129.5$, 128.8, 127.7, 109.7, 83.8, 78.0, 76.4, 75.8, 68.7, 68.6, 27.7, 26.0, 21.4. Anal. Calcd for $\mathrm{C}_{22} \mathrm{H}_{26} \mathrm{O}_{7}$ $\mathrm{S}_{2}$ (466.57): C, 56.63; H, 5.62. Found: C, 56.81; H, 5.49.

Phenyl 2,3-O-isopropylidene-1-thio- $\alpha$-D-rhamnopyranoside (12). Method A. $p$ Toluenesulfonic acid monohydrate $(35 \mathrm{mg})$ and 2,2-dimethoxypropane $(1.0 \mathrm{~mL}, 8.5 \mathrm{mmol})$ were added to a solution of $9(870 \mathrm{mg}, 3.4 \mathrm{mmol})$ in dry DMF $(15 \mathrm{~mL})$. After $7 \mathrm{~h}, \mathrm{NaHCO}_{3}$ was added and the mixture was diluted with $\mathrm{CH}_{2} \mathrm{Cl}_{2}$, washed with water, dried $\left(\mathrm{Na}_{2} \mathrm{SO}_{4}\right)$, filtered and concentrated. Purification by flash chromatography (Hexane/EtOAc 85:15) yielded 12 (604 mg, 60\%): m. p. $82^{\circ} \mathrm{C},[\alpha]_{\mathrm{D}}{ }^{21}+208\left(\right.$ c 1.1 in $\left.\mathrm{CHCl}_{3}\right) ;{ }^{1} \mathrm{H} \mathrm{NMR}\left(200 \mathrm{MHz}, \mathrm{CDCl}_{3}\right) \delta 7.45-7.50(\mathrm{~m}, 2$ H), 7.25-7.31 (m, 3 H), 5.73 (bs, $1 \mathrm{H}, \mathrm{H1}), 4.34$ (dd, $J=0.8,5.6 \mathrm{~Hz}, 1 \mathrm{H}, \mathrm{H} 4), 4.00-4.13$ (m, 2 $\mathrm{H}, \mathrm{H} 2$ and H3), $3.46(\mathrm{~m}, 1 \mathrm{H}, \mathrm{H} 5), 2.15(\mathrm{bs}, 1 \mathrm{H}, \mathrm{OH}), 1.52\left(\mathrm{~s}, 3 \mathrm{H}, \mathrm{CH}_{3}\right), 1.36\left(\mathrm{~s}, 3 \mathrm{H}, \mathrm{CH}_{3}\right)$, 1.29 (d, $J=6.2 \mathrm{~Hz}, 3 \mathrm{H}, \mathrm{CH}_{3}$ ). Anal. Calcd for $\mathrm{C}_{15} \mathrm{H}_{20} \mathrm{O}_{4} \mathrm{~S}$ (296.38): C, 60.79; H, 6.80, S 10.82. Found: C, 56.81; H, 5.49, S 10.73.

Method B. A solution of compound 11 (3.70 g, $7.94 \mathrm{mmol})$ in dry THF (20 mL) was added to a cooled $\left(0{ }^{\circ} \mathrm{C}\right)$ suspension of $\mathrm{LiAlH}_{4}(3.20 \mathrm{~g}, 10 \mathrm{mmol})$ in dry THF $(20 \mathrm{~mL})$. The mixture was allowed to warm to room temperature and then stirred for additional $16 \mathrm{~h}$. The reaction mixture was recooled to $0{ }^{\circ} \mathrm{C}$, diluted with $\mathrm{Et}_{2} \mathrm{O}(100 \mathrm{~mL})$ and then carefully treated with saturated $\mathrm{Na}_{2} \mathrm{SO}_{4}$ solution $(1 \mathrm{~mL})$. The mixture was stirred for $20 \mathrm{~min}$ after which time was filtered though a short pad of celite and concentrated. The residue was purified by flash chromatography. (Hexane/EtOAc 85:15) to afford pure 12 (2.04 g, 87\%).

Phenyl 4-O-benzyl-2,3-O-isopropylidene-1-thio- $\alpha$-D-rhamnopyranoside (13). Compound 12 $(1.22 \mathrm{~g}, 4.12 \mathrm{mmol})$ was dissolved in dry THF $(75 \mathrm{~mL})$, cooled to $0{ }^{\circ} \mathrm{C}$, and treated portionwise with $\mathrm{NaH}(60 \%, 330 \mathrm{mg}, 8.2 \mathrm{mmol}, 2$ equiv.). After $30 \mathrm{~min}$, benzyl bromide $(588 \mu \mathrm{L}$, $4.94 \mathrm{mmol}, 1.2$ equiv.) was added. The reaction mixture was allowed to warm to room 
temperature and stirred overnight. The solution was carefully quenched with water, diluted with $\mathrm{Et}_{2} \mathrm{O}$, washed with $\mathrm{H}_{2} \mathrm{O}$, dried, and concentrated. The product was then purified by flash chromatography (Hexane/EtOAc 85:15) to afford $13(1.44 \mathrm{~g}, 90 \%): \mathrm{m}$. p. $90{ }^{\circ} \mathrm{C}(\mathrm{EtOH}),[\alpha]_{\mathrm{D}}{ }^{21}$ +224 (c 0.97 in $\left.\mathrm{CHCl}_{3}\right) ;{ }^{1} \mathrm{H}$ NMR $\left(200 \mathrm{MHz}, \mathrm{CDCl}_{3}\right) \delta$ 7.51-7.10 (m, $\left.10 \mathrm{H}\right), 5.74(\mathrm{~s}, 1 \mathrm{H}, \mathrm{H} 1)$, $4.93\left(\mathrm{~d}, J=11.6 \mathrm{~Hz}, 1 \mathrm{H}, \mathrm{CH}_{2} \mathrm{Ph}\right), 4.65\left(\mathrm{~d}, J=11.6 \mathrm{~Hz}, 1 \mathrm{H}, \mathrm{CH}_{2} \mathrm{Ph}\right), 4.31-4.39(\mathrm{~m}, 2 \mathrm{H}, \mathrm{H} 2$ and H3), 4.13-4.19 (m, 1 H, H5), 3.32 (dd, $J=6.7,9.9$ Hz, 1 H, H4), 1.52 (s, 3 H, CH 3 ), 1.39 (s, 3 H, $\left.\mathrm{CH}_{3}\right), 1.24\left(\mathrm{~d}, J=6.2 \mathrm{~Hz}, 3 \mathrm{H}, \mathrm{CH}_{3}\right) ;{ }^{13} \mathrm{C} \mathrm{NMR}\left(50 \mathrm{MHz}, \mathrm{CDCl}_{3}\right) \delta 138.5,133.8,132.7,129.3$, 128.6, 128.3, 128.0, 127.8, 109.7, 84.1, 81.7, 78.7, 78.0, 73.4, 66.5, 29.0, 28.3, 26.8, 18.0. $\mathrm{m} / \mathrm{z}$ $387.3\left(\mathrm{M}^{+}+1\right)$, $386.2\left(\mathrm{M}^{+}\right)$. Anal. Calcd for $\mathrm{C}_{22} \mathrm{H}_{26} \mathrm{O}_{4} \mathrm{~S}$ (386.50): C, 68.37; H, 6.78, S 8.30. Found: C, 68.49; H, 6.59, S 8.18.

4-O-Benzyl-2,3-O-isopropylidene- $\boldsymbol{\alpha}$-D-rhamnopyranose $\quad$ (14). Compound $\mathbf{1 3}$ (1.44 g, $3.72 \mathrm{mmol})$ was dissolved in $\mathrm{CH}_{2} \mathrm{Cl}_{2}(15 \mathrm{~mL})$, cooled to $0{ }^{\circ} \mathrm{C}$ and treated with NIS (11.2 mmol, $2.5 \mathrm{~g})$ and $\mathrm{H}_{2} \mathrm{O}(11.2 \mathrm{mmol}, 201 \mu \mathrm{L})$. The mixture was allowed to warm to room temperature and then stirred for additional $2 \mathrm{~h}$. The solution was diluted with $\mathrm{CH}_{2} \mathrm{Cl}_{2}$, successively washed with $\mathrm{Na}_{2} \mathrm{~S}_{2} \mathrm{O}_{3}$, satd aq $\mathrm{NaHCO}_{3}$ and brine. The organic layer was dried and concentrated. Purification by column chromatography (Hexane/EtOAc 80:20) gave hemiketal 14 (680 mg, 62\%) as a (7:3) mixture of anomers ${ }^{1} \mathrm{H}$ NMR $\left(200 \mathrm{MHz}, \mathrm{CDCl}_{3}\right) \delta 7.26-7.36(\mathrm{~m}, 5 \mathrm{H}), 5.35(\mathrm{~d}, J=3.7 \mathrm{~Hz}, 1 \mathrm{H})$, $4.89(\mathrm{~d}, J=11.6 \mathrm{~Hz}, 1 \mathrm{H}), 4.82(\mathrm{~d}, J=11.6 \mathrm{~Hz}, 1 \mathrm{H}), 4.64(\mathrm{~d}, J=11.6 \mathrm{~Hz}, 1 \mathrm{H}), 4.61(\mathrm{~d}, J=$ $11.6 \mathrm{~Hz}, 1 \mathrm{H}), 4.17-4.35$ (m, $2 \mathrm{H}), 3.96(\mathrm{~m}, 1 \mathrm{H}), 3.29$ (dd, $J=6.0,8.3 \mathrm{~Hz}, 1 \mathrm{H}), 3.25$ (dd, $J=$ 6.9, $9.1 \mathrm{~Hz}, 1 \mathrm{H}), 3.00(\mathrm{~d}, J=3.9 \mathrm{~Hz}, 1 \mathrm{H}), 1.52(\mathrm{~s}, 3 \mathrm{H}), 1.51(\mathrm{~s}, 3 \mathrm{H}), 1.40(\mathrm{~s}, 3 \mathrm{H}), 1.38(\mathrm{~s}, 3$ $\mathrm{H}), 1.33(\mathrm{~d}, J=6.3 \mathrm{~Hz}, 3 \mathrm{H}), 1.28(\mathrm{~d}, J=6.3 \mathrm{~Hz}, 3 \mathrm{H}) ;{ }^{13} \mathrm{C} \mathrm{NMR}\left(50 \mathrm{MHz}, \mathrm{CDCl}_{3}\right) \delta 145.9$, $128.3,128.1,128.0,127.9,127.8,127.7,110.2,109.2,92.4,92.1,80.6,80.1,78.7,77.9,76.1$, $74.9,73.0,72.6,71.1,65.1,27.9,27.6,26.2,18.8,18.1$

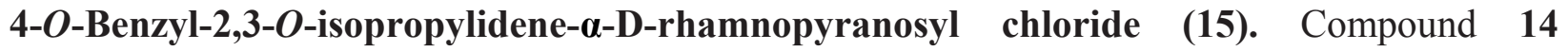
$(51 \mathrm{mg}, 0.17 \mathrm{mmol})$ and $N, N$-dimethylformamide $(17 \mu \mathrm{L})$ were dissolved in $\operatorname{dry~} \mathrm{CH}_{2} \mathrm{Cl}_{2}(2 \mathrm{~mL})$, and then a solution of oxalyl chloride ( $43 \mu \mathrm{L}, 0.51 \mathrm{mmol}, 3$ equiv.) in dry $\mathrm{CH}_{2} \mathrm{Cl}_{2}$ ( $1 \mathrm{~mL}$ ) was added dropwise at $0{ }^{\circ} \mathrm{C}$. The mixture was stirred at that temperature for $30 \mathrm{~min}$ after which time was allowed to warm to room temperature and stirred for one additional hour. The reaction crude was then concentrated, the residue taken up in 1:1 EtOAc/hexane and the suspension filtered through silica gel, to give after evaporation of the solvents, chloride 15 (36 mg, 68\%): ${ }^{1} \mathrm{H} \mathrm{NMR}$ (300 MHz, $\left.\mathrm{CDCl}_{3}\right): 7.26-7.50(\mathrm{~m}, 5 \mathrm{H}), 6.27(\mathrm{~s}, 1 \mathrm{H}, 1-\mathrm{H}), 4.92\left(\mathrm{~d}, J=11.5 \mathrm{~Hz}, 1 \mathrm{H}, \mathrm{CH}_{2} \mathrm{Ph}\right)$, $4.64\left(\mathrm{~d}, J=11.5 \mathrm{~Hz}, 1 \mathrm{H}, \mathrm{CH}_{2} \mathrm{Ph}, 4.31(\mathrm{~m}, 1 \mathrm{H}, 3-\mathrm{H}), 4.12\right.$ (d, $\left.J=4.9 \mathrm{~Hz}, 1 \mathrm{H}, 2-\mathrm{H}\right), 3.75$ (dd, $J$ = 6.2, $9.7 \mathrm{~Hz}, 1 \mathrm{H}, 5-\mathrm{H}), 3.26(\mathrm{dd}, \mathrm{J}=7.2,9.7 \mathrm{~Hz}, 1 \mathrm{H}, 4-\mathrm{H}), 1.52\left(\mathrm{~s}, 3 \mathrm{H}, \mathrm{CH}_{3}\right), 1.38(\mathrm{~s}, 3 \mathrm{H}$, $\left.\mathrm{CH}_{3}\right), 1.29\left(\mathrm{~d}, \mathrm{~J}=6.2 \mathrm{~Hz}, \mathrm{CH}_{3}\right) ; \mathrm{m} / \mathrm{z} 312.1\left(\mathrm{M}^{+}, \mathrm{C}_{16} \mathrm{H}_{21} \mathrm{ClO}_{4}\right.$ requires 312,1128), $314.2\left(\mathrm{M}^{+}+2\right)$.

\section{General procedure for C-1 glycal formation}

A solution of the glycosyl chloride $(1 \mathrm{mmol})$ in dry THF was cooled to the appropriate temperature and then treated with the corresponding organolithium reagent. After stirring for a period of time between $0.5-2 \mathrm{~h}$ and once TLC analyses showed total disappearance of the starting material, the reaction mixture was quenched with a saturated aqueous solution of $\mathrm{NH}_{4} \mathrm{Cl}$. 
After partitioning between water and diethyl ether, the organic layer was dried over $\mathrm{MgSO}_{4}$ and concentrated. The residue was purified by flash chromatography.

1,4-Anhydro-5,6-O-isopropyliden-2-deoxy-1-C-phenyl-D-arabino-hex-1-enitol (16). Using the general procedure, chloride $6(87 \mathrm{mg}, 0.32 \mathrm{mmol})$ was treated with $\mathrm{PhLi}(0.53 \mathrm{~mL} 1.8 \mathrm{M}$ solution in di-n-butylether, $0.96 \mathrm{mmol}$ ) at $0{ }^{\circ} \mathrm{C}$. Extractive work-up was followed by a quick flash chromatography (EtOAc/hexane $20 \%)$ to give C-1 glycal $16(58 \mathrm{mg}, 71 \%)$ : $[\alpha]_{\mathrm{D}}{ }^{25}+7.8(\mathrm{c}$ 0.33 in $\left.\mathrm{CHCl}_{3}\right) ;{ }^{1} \mathrm{H} \mathrm{NMR} \delta\left(\mathrm{C}_{6} \mathrm{D}_{6}, 300 \mathrm{MHz}\right) 1.31(3 \mathrm{H}, \mathrm{s}, \mathrm{Me}), 1.45(3 \mathrm{H}, \mathrm{s}, \mathrm{Me}), 4.10(2 \mathrm{H}, \mathrm{m}$, 6-H), 4.25 (1 H, t, J 6.7, 4-H), 4.55 (1 H, m, 5-H), 4.70 (1 H, dd, J 2.9, 6.7, 3-H), 5.39 (1 H, d, J 2.9, 2-H), 7.10 (3 H, m, Ph), 7.56 (2 H, m, Ph). ${ }^{13} \mathrm{C}$ NMR $\delta\left(\mathrm{C}_{6} \mathrm{D}_{6}, 50 \mathrm{MHz}\right) 25.5,27.0,67.0$, 73.6, 74.0, 85.6, 99.2, 109.2, 124.1, 125.9, 128.3, 129.4, 159.8. m/z 263.1 $\left(\mathrm{M}^{+}+1 ; \mathrm{C}_{15} \mathrm{H}_{18} \mathrm{O}_{4}\right.$ requires 262.1205$)$.

1,5-Anhydro-4-benzyl-2,6-dideoxy-1-C-phenyl-D-arabino-hex-1-enitol (17). Using the general procedure, chloride $15(37 \mathrm{mg}, 0.12 \mathrm{mmol})$ was treated with $\mathrm{PhLi}(510 \mu \mathrm{L} 1.5 \mathrm{M}$ solution in diethyl-ether, $0.72 \mathrm{mmol}$ ) at room temperature. Extractive work-up was followed by flash chromatography (EtOAc/hexane 20\%) to give C-1 glycal 17 (15.2 mg, 43\%): ${ }^{1} \mathrm{H}$ NMR $\delta\left(\mathrm{CDCl}_{3}, 300 \mathrm{MHz}\right) 1.29\left(\mathrm{~d}, J=5.5 \mathrm{~Hz}, 3 \mathrm{H}, \mathrm{CH}_{3}\right), 3.37-3.58(\mathrm{~m}, 2 \mathrm{H}, 4-\mathrm{H}$ and 5-H), 4.25 (br s, $1 \mathrm{H}, 3-\mathrm{H}), 4.61$ (d, $J=11.6 \mathrm{~Hz}, 1 \mathrm{H}, \mathrm{CH}_{2} \mathrm{Ph}$ ), 4.84 (d, $J=11.6 \mathrm{~Hz}, 1 \mathrm{H}, \mathrm{CH}_{2} \mathrm{Ph}$ ), 5.35 (br. S, $1 \mathrm{H}$, 2-H), 7.27-7.36 (m, $5 \mathrm{H}) ;{ }^{13} \mathrm{C} \mathrm{NMR} \delta\left(\mathrm{CDCl}_{3}, 50 \mathrm{MHz}\right) 18.9,71.0,73.0,79.6,80.2,96.9,127.5$, 127.7, 127.9, 128.0, 128.2, 128.3, 138.1, 148.1; m/z 297.1 $\left(\mathrm{M}^{+}+1\right)$. Anal. Calcd for $\mathrm{C}_{19} \mathrm{H}_{20} \mathrm{O}_{3}$ (296.1412): C, 77.00; H, 6.80. Found: C, 76.83; H, 6.88.

\section{1,4-Anhydro-5,6-O-isopropyliden-2-deoxy-1-C-1-(methoxy-2-napthyl)-D-arabino-hex-1-} enitol (18). A cooled $\left(-78{ }^{\circ} \mathrm{C}\right)$ solution of 1-methoxynaphtalene $(293 \mu \mathrm{L}, 2 \mathrm{mmol})$ in dry THF $(1 \mathrm{~mL})$ was treated with $t$-BuLi $(1.17 \mathrm{~mL}, 1.7 \mathrm{M}$ solution in pentane, $2 \mathrm{mmol})$ and the reaction mixture was allowed to warm to $0{ }^{\circ} \mathrm{C}$ and then stirred for $2 \mathrm{~h}$. Chloride 6 (98 $\mathrm{mg}, 0.35 \mathrm{mmol}$ ) dissolved in dry THF ( $2 \mathrm{~mL})$ was then added and the mixture was stirred at room temperature for $3 \mathrm{~h}$. The reaction mixture was quenched with a saturated aqueous solution of $\mathrm{NH}_{4} \mathrm{Cl}$ and after partitioning between water and diethyl ether, the organic layer was dried over $\mathrm{MgSO}_{4}$ and concentrated. The residue was purified by flash chromatography. (EtOAc/hexane 10\%) to give C-1 glycal, 18 (55 mg, 46\%): $\left.[\alpha]_{\mathrm{D}}{ }^{25}=+48.7(c) .79, \mathrm{CHCl}_{3}\right) ;{ }^{1} \mathrm{H}$ NMR $\delta\left(\mathrm{CDCl}_{3}, 300 \mathrm{MHz}\right) 1.44$ (s, 3H, Me), 1.53 (s, 3H, Me), 3.94 (s, 3H, OMe), 3.90-4.41 (m, 3H), 4.65 (ddd, J= 5.3, 7.9, 11.2 Hz, 1 H, H5), 5.16 (dd. $J=2.6,6.4,1 \mathrm{H}, \mathrm{H} 3$ ), 6.10 (d, $J=2.6$ Hz, 1 H, H2), 7.40-8.19 (m, 6 H). $\mathrm{m} / \mathrm{z} 342.0\left(\mathrm{M}^{+} . \mathrm{C}_{20} \mathrm{H}_{22} \mathrm{O}_{5}\right.$ requires 342.1467), 324.0, 306.0, 253.0, 242.0, 225.0, 186.0.

(R)-4-[5-(1-Methoxynaphthalen-2-yl)furan-2-yl]-2,2-dimethyl-1,3-dioxolane (19). Compound 18 (50 mg, $0.15 \mathrm{mmol}$ ) was dissolved in dry $\mathrm{CH}_{2} \mathrm{Cl}_{2}$ and treated with silica gel. The mixture was boiled for $30 \mathrm{~min}$ under reflux. After cooling, the reaction mixture was concentrated. Flash chromatography ((EtOAc/hexane 5\%) gave 19 (47 mg, 100\%); ${ }^{1} \mathrm{H}$ NMR $\delta\left(\mathrm{CDCl}_{3}, 300 \mathrm{MHz}\right)$ 1.50 (s, 3H, Me), 1.59 (s, 3H, Me), 3.90 (s, 3H, OMe), 4.19-4.36 (m, 2H), $5.20(\mathrm{~m}, 1 \mathrm{H}), 6.55$ (d, $J=3.4 \mathrm{~Hz}, 1 \mathrm{H}), 7.05(\mathrm{~d}, J=3.4 \mathrm{~Hz}, 1 \mathrm{H}), 7.46-7.57(\mathrm{~m}, 2 \mathrm{H}), 7.65$ ( d, $J=8.8 \mathrm{~Hz}, 1 \mathrm{H}), 7.82$ $(\mathrm{m}, 1 \mathrm{H}), 7.94(\mathrm{~d}, J=8.7 \mathrm{~Hz}, 1 \mathrm{H}), 8.15(\mathrm{~m}, 1 \mathrm{H}) ; \mathrm{m} / \mathrm{z} 324.37\left(\mathrm{M}^{+}\right)$. Anal. Calcd for $\mathrm{C}_{20} \mathrm{H}_{20} \mathrm{O}_{4}$ (324,3704): C, 74.06; H, 6.21. Found: C, 73.98; H, 6.29. 


\section{1,4-Anhydro-5,6-O-isopropyliden-2-deoxy-1-C(-3-methoxy-2-naphthyl)-D-arabino-hex-1-} enitol (20). A cooled $\left(-78^{\circ} \mathrm{C}\right)$ solution of 2-methoxynaphthalene $(316 \mathrm{mg}, 2 \mathrm{mmol})$ in dry THF $(1 \mathrm{~mL})$ was treated with $t$-BuLi $(1.17 \mathrm{~mL} 1.7 \mathrm{M}$ solution in pentane, $2 \mathrm{mmol})$ and the reaction mixture was allowed to warm to $0{ }^{\circ} \mathrm{C}$ and then stirred for $2 \mathrm{~h}$. Chloride 6 ( $\left.81 \mathrm{mg}, 0.29 \mathrm{mmol}\right)$ dissolved in dry THF $(2 \mathrm{~mL})$ was then added and the mixture was stirred at room temperature for 3h. The reaction mixture was quenched with a saturated aqueous solution of $\mathrm{NH}_{4} \mathrm{Cl}$ and after partitioning between water and diethyl ether, the organic layer was dried over $\mathrm{MgSO}_{4}$ and concentrated. The residue was purified by flash chromatography. (EtOAc/hexane 15\%) to give C-1 glycal 20 (35 mg, 35\%): $[\alpha]_{\mathrm{D}}{ }^{25}=-7.2\left(c 0.67, \mathrm{CHCl}_{3}\right) ;{ }^{1} \mathrm{H} \mathrm{NMR} \delta\left(\mathrm{CDCl}_{3}, 300 \mathrm{MHz}\right) 1.45$ (s, 3H, Me), 1.54 (s, 3H, Me), 1.97 (bd, $J=5.2 \mathrm{~Hz}, 1 \mathrm{H}), 4.00$ (s, 3H, OMe), 4.21-4.39 (m, 3H), 4.65 (ddd, $J=5.3,7.9,11.2 \mathrm{~Hz}, 1 \mathrm{H}, \mathrm{H} 5), 5.14$ (dd. $J=2.9,6.4,1 \mathrm{H}, \mathrm{H} 3$ ), 6.17 (d, $J=2.9 \mathrm{~Hz}, 1$ $\mathrm{H}, \mathrm{H} 2), 7.34-7.50(\mathrm{~m}, 2 \mathrm{H}), 7.70-7.83(\mathrm{~m}, 2 \mathrm{H}), 8.16(\mathrm{~s}, 1 \mathrm{H}) ;{ }^{13} \mathrm{C} \mathrm{NMR}\left(50 \mathrm{MHz}, \mathrm{CDCl}_{3}\right) \delta$ 25.4, 27.0, 55.4, 67.2, 73.3, 74.8, 83.4, 104.5, 105.7, 109.4, 124.1, 126.3, 127.3, 128.2, 128.4, $128.5,134.5,155.4,155.5 ; . \mathrm{m} / \mathrm{z} 342.0\left(\mathrm{M}^{+}\right)$.

(R)-4-[5-(3-Methoxynaphthalen-2-yl)furan-2-yl]-2,2-dimethyl-1,3-dioxolane (21). Compound 20 (25 mg, $0.077 \mathrm{mmol}$ ) was dissolved in dry $\mathrm{CH}_{2} \mathrm{Cl}_{2}$ and treated with silica gel. The mixture was boiled for $30 \mathrm{~min}$ under reflux. After cooling, the reaction mixture was concentrated. Flash chromatography ((EtOAc/hexane 5\%) gave 21 (24 mg, 100\%); ${ }^{1} \mathrm{H}$ NMR $\delta\left(\mathrm{CDCl}_{3}, 300 \mathrm{MHz}\right)$ $1.52(\mathrm{~s}, 3 \mathrm{H}, \mathrm{Me}), 1.61(\mathrm{~s}, 3 \mathrm{H}, \mathrm{Me}), 4.04(\mathrm{~s}, 3 \mathrm{H}, \mathrm{OMe}), 4.21-4.38(\mathrm{~m}, 2 \mathrm{H}), 5.23(\mathrm{t}, J=6.9 \mathrm{~Hz}, 1$ H), $6.51(\mathrm{~d}, J=3.3 \mathrm{~Hz}, 1 \mathrm{H}), 7.03(\mathrm{~d}, J=3.3 \mathrm{~Hz}, 1 \mathrm{H}), 7.20(\mathrm{~s}, 1 \mathrm{H}), 7.36-7.45(\mathrm{~m}, 2 \mathrm{H}), 7.73(\mathrm{~m}$, $1 \mathrm{H}), 7.84(\mathrm{~m}, 1 \mathrm{H}), 8.23(\mathrm{~s}, 1 \mathrm{H}) ; \mathrm{m} / \mathrm{z} 324.0\left(\mathrm{M}^{+}\right)$;. Anal. Calcd for $\mathrm{C}_{20} \mathrm{H}_{20} \mathrm{O}_{4}(324,3704)$ : $\mathrm{C}$, 74.06; H, 6.21. Found: C, 73.87; H, 6.13.

\section{Reaction of furanosyl chloride 6 with 1-naphthol. General procedure}

A cooled $\left(-78^{\circ} \mathrm{C}\right)$ solution of 1-naphthol $(228 \mathrm{mg}, 2 \mathrm{mmol})$ in dry THF $(1 \mathrm{~mL})$ was treated with $t$-BuLi $(3.0 \mathrm{~mL} 1.5 \mathrm{M}$ solution in pentane, $4.5 \mathrm{mmol})$ and the reaction mixture was allowed to warm to $0{ }^{\circ} \mathrm{C}$ and then stirred for $2 \mathrm{~h}$. Chloride $6(98 \mathrm{mg}, 0.33 \mathrm{mmol})$ dissolved in dry THF $(2 \mathrm{~mL})$ was then added and the mixture was stirred at room temperature for $3 \mathrm{~h}$. The reaction mixture was quenched with a saturated aqueous solution of $\mathrm{NH}_{4} \mathrm{Cl}$ and after partitioning between water and diethyl ether, the organic layer was dried over $\mathrm{MgSO}_{4}$ and concentrated. The residue was purified by flash chromatography. (EtOAc/hexane 15\%) to give an inseparable mixture of C-1 glycal 21 and furane 22 (35 mg, ratio 21/22 5:3): ${ }^{1} \mathrm{H} \mathrm{NMR} \delta\left(\mathrm{CDCl}_{3}, 300 \mathrm{MHz}\right) 1.38(\mathrm{~s}, 3 \mathrm{H}$,

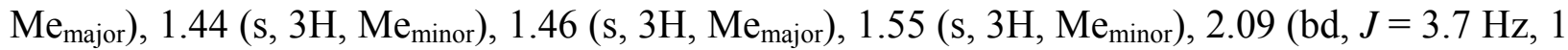
$\mathrm{H}_{\text {major }}$ ), 2.88 (m, $1 \mathrm{H}_{\text {minor }}$ ), 3.83-5.00 (m, $4 \mathrm{H}_{\text {major }}+3 \mathrm{H}_{\text {minor }}$ ), 5.21 (m, $1 \mathrm{H}_{\text {major }}$ ), 6.10 (d, J = 3.3 $\mathrm{Hz}, 1 \mathrm{H}_{\text {major }}$ ), 6.54 (d, J = 3.4 Hz, $\left.1 \mathrm{H}_{\text {minor }}\right), 7.04$ (d, J = 3.4 Hz, $\left.1 \mathrm{H}_{\text {minor }}\right), 7.40-8.30$ (m, $6 \mathrm{H}_{\text {major }}$ $+6 \mathrm{H}_{\text {minor }}$ ).

1,5-Bis(ethoxymethoxy)anthracene-9,10-dione (25). A suspension of $1.00 \mathrm{~g}(4.2 \mathrm{mmol})$ of anthrarufin $(1.5 \mathrm{~g}, 6.2 \mathrm{mmol})$ in chloroform $(20 \mathrm{~mL})$ was treated with $13.5 \mathrm{~mL}(77.6 \mathrm{mmol})$ of $N$, $N$-diisopropylethylamine $(19.6 \mathrm{~mL}, 114.7 \mathrm{mmol})$ and chloromethyl ethyl ether $(6.9 \mathrm{~mL}$, $74.4 \mathrm{mmol}$ ) and was subsequently heated to reflux for $20 \mathrm{~h}$. The mixture was allowed to cool to 
room temperature and was washed with aqueous $\mathrm{NaOH}(1 \mathrm{~N})$ solution, followed by brine. The organic phase was dried over $\mathrm{MgSO}_{4}$, and the solvent was evaporated. The resulting solid was washed successively with $1 \mathrm{~N} \mathrm{NaOH}$, water, and absolute ethanol to afford anthraquinone 25 (1.76 g, 82\% yield) as a yellow solid: m.p $155-156{ }^{\circ} \mathrm{C} ;{ }^{1} \mathrm{H}$ NMR $\delta\left(\mathrm{CDCl}_{3}, 300 \mathrm{MHz}\right): 1.22(\mathrm{t}, J$ $=7.0 \mathrm{~Hz}, 6 \mathrm{H}), 3.83(\mathrm{q}, J=7.0 \mathrm{~Hz}, 4 \mathrm{H}) ; 5.43(\mathrm{~s}, 4 \mathrm{H}), 7.53(\mathrm{dd}, J=1.2,8.4 \mathrm{~Hz}, 2 \mathrm{H}), 7.66(\mathrm{dd}, J$ $=7.6,8.4 \mathrm{~Hz}, 2 \mathrm{H}), 7.94(\mathrm{dd}, J=1.2,7.6 \mathrm{~Hz}, 2 \mathrm{H}) ;{ }^{13} \mathrm{C} \mathrm{NMR}\left(50 \mathrm{MHz}, \mathrm{CDCl}_{3}\right) \delta$ 15.0, 64.9, 93.8, 105.2, 120.8, 121.2, 134.7, 137.3, 157.3, 182.4; m/z 356.0 (M $\left.{ }^{+}\right)$; Anal. Calcd for $\mathrm{C}_{20} \mathrm{H}_{20} \mathrm{O}_{6}$ (356,3692): C, 67.41; H, 5.66. Found: C, 67.27; H, 5.43.

1,5-Bis(ethoxymethoxy)anthracene (26). To a suspension of anthraquinone 25 (1.54 g, $4.3 \mathrm{mmol})$ in 2-propanol $(60 \mathrm{~mL})$ was added $\mathrm{NaBH}_{4}(4.9 \mathrm{~g}, 130 \mathrm{mmol})$. The mixture was heated to reflux for $8 \mathrm{~h}$, poured onto ice water, and treated slowly with $6 \mathrm{~N} \mathrm{HCl}$ at $0{ }^{\circ} \mathrm{C}$ until the pH of the mixture was 4-6. The solid anthracene was filtered, and the aqueous fraction was extracted with $\mathrm{CH}_{2} \mathrm{Cl}_{2}$. The organic phase was washed with water and dried over $\mathrm{MgSO}_{4}$, and the solvent was evaporated to produce additional crude anthracene as a yellow-brown solid. Flash column chromatography of the combined solids gave $6(1.2 \mathrm{~g}, 85 \%)$ as a pale yellow solid: $\mathrm{mp} 88-89{ }^{\circ} \mathrm{C}$; ${ }^{1} \mathrm{H} \mathrm{NMR} \delta\left(\mathrm{CDCl}_{3}, 300 \mathrm{MHz}\right): 1.28(\mathrm{t}, J=7.0 \mathrm{~Hz}, 6 \mathrm{H}), 3.87(\mathrm{q}, J=7.0 \mathrm{~Hz}, 4 \mathrm{H}) ; 5.53(\mathrm{~s}, 4 \mathrm{H})$, 7.06 (d, $J=7.4 \mathrm{~Hz}, 2 \mathrm{H}), 7.36$ (dd, $J=7.4,8.5 \mathrm{~Hz}, 2 \mathrm{H}), 7.69$ (d, $J=8.5 \mathrm{~Hz}, 2 \mathrm{H}), 8.79$ (s, $2 \mathrm{H}$ ); ${ }^{13} \mathrm{C} \mathrm{NMR}\left(50 \mathrm{MHz}, \mathrm{CDCl}_{3}\right) \delta 15.1,64.6,93.4,105.8,120.5,121.9,125.1,125.4,132.2,152.8$; m/z $326.0\left(\mathrm{M}^{+}\right)$; Anal. Calcd for $\mathrm{C}_{20} \mathrm{H}_{22} \mathrm{O}_{4}(326,3863)$ : C, 73.60; H, 6.79. Found: C, 73.51; H, 6.63 .

\section{Reaction of furanosyl chloride 6 with 1-naphthol. General procedure}

A cooled $\left(-78^{\circ} \mathrm{C}\right)$ solution of 1-naphthol $(228 \mathrm{mg}, 2 \mathrm{mmol})$ in dry THF $(1 \mathrm{~mL})$ was treated with $t$-BuLi $(3.0 \mathrm{~mL} 1.5 \mathrm{M}$ solution in pentane, $4.5 \mathrm{mmol})$ and the reaction mixture was allowed to warm to $0^{\circ} \mathrm{C}$ and then stirred for $2 \mathrm{~h}$. Chloride $6(98 \mathrm{mg}, 0.33 \mathrm{mmol})$ dissolved in dry THF $(2 \mathrm{~mL})$ was then added and the mixture was stirred at room temperature for $3 \mathrm{~h}$. The reaction mixture was quenched with a saturated aqueous solution of $\mathrm{NH}_{4} \mathrm{Cl}$ and after partitioning between water and diethyl ether, the organic layer was dried over $\mathrm{MgSO}_{4}$ and concentrated. The residue was purified by flash chromatography. (EtOAc/hexane 15\%) to give an inseparable mixture of C-1 glycal 21 and furane 22 (35 mg, ratio 21/22 5:3): ${ }^{1} \mathrm{H}$ NMR $\delta\left(\mathrm{CDCl}_{3}, 300 \mathrm{MHz}\right) 1.38(\mathrm{~s}, 3 \mathrm{H}$,

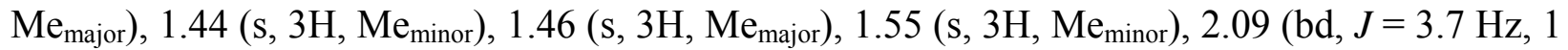
$\mathrm{H}_{\text {major }}$ ), 2.88 (m, $\left.1 \mathrm{H}_{\text {minor }}\right), 3.83-5.00$ ( $\left.\mathrm{m}, 4 \mathrm{H}_{\text {major }}+3 \mathrm{H}_{\text {minor }}\right), 5.21$ (m, $\left.1 \mathrm{H}_{\text {major }}\right), 6.10(\mathrm{~d}, \mathrm{~J}=3.3$ $\mathrm{Hz}, 1 \mathrm{H}_{\text {major }}$ ), 6.54 (d, J = 3.4 Hz, $\left.1 \mathrm{H}_{\text {minor }}\right), 7.04$ (d, J = 3.4 Hz, $\left.1 \mathrm{H}_{\text {minor }}\right), 7.40-8.30$ (m, $6 \mathrm{H}_{\text {major }}$ $+6 \mathrm{H}_{\text {minor }}$ ). 


\section{Acknowledgements}

This research has been supported with funds from the Ministerio de Ciencia y Tecnología (Grant CTQ-2006-C03). M.C. is grateful to the Ministerio de Educación y Ciencia for a predoctoral scholarship.

\section{References}

1. (a) Franz, H. H.; Gross, P. H.; Samoshin, V. V. Arkivoc 2008, (i), 271. (b) Ferrier, R. J.; Hoberg, J. O. Adv. Carbohydr. Chem. Biochem. 2003, 58, 5. (c) Ferrier, R. J.; Zubkov, O. A. Org. React. 2003, 62, 569. (d) Ferrier, R. J. Topics in Current Chemistry, Springer: Berlin, 2001, Vol. 215, pp 153. (e) Somsák, L. Chem. Rev. 2001, 101, 81. (f) Priebe, W.; Grynkiewicz, G. In Glycoscience: Chemistry and Chemical Biology, Fraser- Reid, B.; Tatsuta, K.; Thiem, J., Eds., Springer: Heidelberg, 2001, p 749. (g) Fraser-Reid, B. Acc. Chem. Res. 1985, 18, 347. (h) Fraser-Reid, B. Acc. Chem. Res. 1975, 8, 192. (i) Ferrier, R. J. Adv. Carbohydr. Chem. Biochem. 1970, 24, 199.

2. (a) Hultin, P. G. Curr. Top. Med. Chem. 2005, 5, 1299. (b) Zou, W. Curr. Top. Med. Chem. 2005, 5, 1363. (c) Beau, J.-M.; Gallagher, T. Top. Curr. Chem. 1997, 187, 1. (d) Nicotra, F. Top. Curr. Chem. 1997, 187, 55. (e) Postema, M. H. D. C-Glycoside Synthesis; CRC Press, Inc.: Boca Raton, FL, 1995. (f) Meo, P.; Osborn, H. M. I. Best Synthetic Methods: Carbohydrates; Elsevier Science Ltd.: New York, 2003; pp 337-384. (g) Du, Y.; Linhardt, R. J.; Vlahov, I. R. Tetrahedron 1998, 54, 9913.

3 (a) Compain, P.; Martin, O. R. Bioorg. Med. Chem. 2001, 9, 3077. (b) Carbohydrate Mimics. Concepts and Methods; Chapleur, Y. Ed.; Wiley-VCH: Weinheim, New York, 1998. (c) Sears, P.; Wong, C.-H. Angew. Chem., Int. Ed. 1999, 38, 2300. (d) Stolz, F.; Blume, A.; Reutter, W.; Schmidt, R. R. J. Org. Chem. 2004, 69, 665; (e) Yu, J.; Hsieh, L. C.; Kochersperger, L.; Yonkovich, S.; Stephans, J. C.; Gallop, M. A.; Schultz, P. G. Angew. Chem., Int. Ed. Engl. 1994, 33, 339. (f) Frische, K.; Schmidt, R. R. Liebigs Ann. Chem. 1994, 297. (g) Schmidt, R. R.; Frische, K. Bioorg. Med. Chem. Lett. 1993, 3, 1747. (h) Lai, E. C. K.; Morris, S. A; Street, I. P.; Withers, S. G. Bioorg. Med. Chem. 1996, 4, 1929.

4 (a) Nicolaou, K. C.; Vyskocil, S.; Koftis, T. V.; Yamada, Y. M. A.; Ling, T.; Chen, D. Y.-K.; Tang, W.; Petrovic, G.; Frederick, M. O.; Li, Y.; Satake, M. Angew. Chem., Int. Ed. 2004, 43, 4312. (b) Nicolaou, K. C.; Koftis, T. V.; Vyskocil, S.; Petrovic, G.; Tang, W.; Frederick, M. O.; Chen, D. Y.-K.; Li, Y.; Ling, T.; Yamada, Y. M. A. J. Am. Chem. Soc. 2006, 128, 2859. (c) Nicolaou, K. C.; Frederick, M. O.; Petrovic, G.; Cole, K. P.; Loizidou, E. Z. Angew. Chem., Int. Ed. 2006, 45, 2609. (d) Fuwa, H.; Naito, S.; Goto, T.; Sasaki, M. Angew. Chem. Int. Ed. Engl. 2008, 47, 4737. (e) Fuwa, H.; Sasaki, M. Org. Lett. 2008, 10, 2549.

5 Reviews: (a) Jarosz, S.; Zamojski, A. Curr. Org. Chem. 2003, 7, 1. (b) Friesen, R. W. J. Chem. Soc., Perkin Trans. 1, 2001, 1969. 
6 (a) Postema, M. H. D.; Piper, J. L. Betts, R. L. Synlett 2005, 1345. (b) Postema, M. H. D.; Calimente, D. J. Org. Chem. 1999, 64, 177.

7 (a) N. Khan, N.; Cheng, X.; Mootoo, D. R. J. Am. Chem. Soc., 1999, 121, 4918. (b) Tony, K. A.; Denton, R. W.; Dilhas, A.; Jiménez-Barbero, J.; Mootoo, D. R. Org. Lett. 2007, 9, 1441.

8 Lesimple, P.; Beau, J.-M.; Jaurand, G.; Sinaÿ, P. Tetrahedron Lett. 1986, 27, 6201.

9 Nicolaou, K. C.; Hwang, C.-K.; Duggan, M. E. J. Chem. Soc., Chem. Commun. 1986, 925.

10 Hanessian, S.; Martin, M.; Desai, R. C. J. Chem. Soc., Chem. Commun. 1986, 926.

11 (a) Dubois, E.; Beau, J.-M. J. Chem. Soc., Chem. Commun. 1990, 1191. (b) Dubois, E.; Beau, J.-M. Tetrahedron Lett. 1990, 31, 5165. (c) Dubois, E.; Beau, J.-M. Carbohydr Res., 1992, 228, 103.

12 (a) Friesen, R. W. Sturino, C. F. J. Org. Chem. 1990, 55, 2572. (b) Friesen, R. W.; Sturino, C. F. J. Org. Chem. 1990, 55, 5808. (c) Friesen, R. W.; Loo, R. W. J. Org. Chem. 1991, 56, 4821. (d) Friesen, R. W.; Loo, R. W.; Sturino, C. F. Can. J. Chem. 1994, 72, 1262.

13 (a) Zhang, H.-C.; Brakta, M.; Daves, G. D. Jr, Tetrahedron Lett. 1993, 34, 1571. (b) Abas, A.; Beddoes, R. L.; Conway, J. C.; Quayle, P.; Urch, C. J. Synlett 1995, 1264. (c) Koo, B.; McDonald, F. E. Org. Lett., 2005, 7, 3621. (d) Jeanneret, V.; Meerpoel, L.; Vogel, P. Tetrahedron Lett. 1997, 38, 543. (e) Steunenberg, P.; Jeanneret, V.; Zhu, Y.-H.; Vogel, P. Tetrahedron: Asymm. 2005, 16, 337. (f) Dubbaka, S. R.; Steunenberg, P.; Vogel, P. Synlett 2004, 1235. (g) Dubbaka, S. R.; Steunenberg, P. Vogel, P. Synlett 2004, 1235.

14 (a) Boyd, V. A.; Drake, B. E.; Sulikowski, G. A. J. Org. Chem. 1993, 58, 3191. (b) McDonald, F. E.; Zhu, H. Y. H.; Holmquist, C. R. J. Am. Chem. Soc., 1995, 117, 6605. (c) Li, H.; Procko, K.; Martin, S. F. Tetrahedron Lett. 2006, 47, 3485.

15 (a) Gómez, A. M.; Pedregosa, A.; Valverde, S.; López, J. C. Chem. Commun. 2002, 2022. (b) Gómez, A. M.; Danelón, G. O.; Pedregosa, A.; Valverde, S.; López, J. C. Chem. Commun. 2002, 2024. (c) Gómez, A. M.; Barrio, A.; Pedregosa, A.; Valverde, S.; López, J. C. Tetrahedron Lett. 2003, 44, 8433.

16 Gómez, A. M.; Casillas, M.; Valverde, S.; López, J. C. J. Chem. Soc., Chem. Commun. 1996, 2357.

17 Harusawa, S.; Kawabata, M.; Murai, Y.; Yoneda, R.; Kurihara, T. Chem. Pharm. Bull. 1995, 43, 152.

18 Gómez, A. M.; Pedregosa, A.; Casillas, M.; Uriel, C.; López, J. C. Eur. J. Org. Chem. 2009, 3579.

19 Basha, A.; Henry, R.; McLaughlin, M. A.; Ratajczyk, J. D.; Wittenberger, S. J. J. Org. Chem. 1994, 59, 6103.

20 Ireland, R. E.; Thaisrivongs, S.; Vanier, N.; Wilcox, C. S. J. Org. Chem. 1980, 45, 48.

21 (a) Tius, M. A.; Gomez-Galeno, J.; Gu, X. Q.; Zaidi, J. H. J. Am. Chem. Soc. 1991, 113, 5775; (b) Tius, M. A.; Gu, X. Q.; Gomez-Galeno, J. J. Am. Chem. Soc., 1990, 112, 5775.

22 (a) Snieckus, V. Chem. Rev. 1990, 90, 879. (b) Hartung, C. G.; Snieckus, V. in Modern Arene Chemistry; Astruc, D. Ed.; Wiley-VCH: Weinheim, Germany, 2002; pp 330-367. (c) 
Macklin, T.; Snieckus, V. in Handbook of C-H Transformations; Dyker, G. Ed.; Wiley: Weinheim, 2005; pp 106-118.

23 (a) B. Ernst, T. Winkler, Tetrahedron Lett. 1989, 30, 3081. (b) R. M. Cicchillo, P. Norris Carbohydr. Res. 2000, 328, 431.

24 J. Kerékgyártó, Z. Szurmai, A. Lipták, Carbohydr. Res. 1993, 245, 65. 